\title{
Relationships between breast muscle thickness measured by ultrasonography and meatiness and fatness in broiler chickens
}

\author{
KATARZYNA KLECZEK'1, KAZIMIERZ WAWRO', ELŻBIETA WILKIEWICZ-WAWRO', \\ WŁODZIMIERZ MAKOWSKI ${ }^{1}$ and DANIEL KONSTANTYNOWICZ ${ }^{2}$
}

'Department of Commodity Science and Animal Improvement, University of Warmia and Mazury, Olsztyn, Poland, ${ }^{2}$ DRAMINSKI - Electronics in Agriculture, Olsztyn, Poland

\section{Abstract}

The objective of this study was to determine relationships between breast muscle thickness measured by ultrasonography and meatiness and fatness characteristics in broiler chickens. The experiment was conducted on 80 Ross 308 chickens aged 42 days. Breast muscle thickness was determined before and after slaughter, using an ultrasonic diagnostic apparatus (Dramiński Animal Scanner with an abdominal, sector mechanical probe). The chickens were weighed and carcasses were subjected to detailed dissection.

In males breast muscle thickness measured before slaughter was found to be statistically correlated with the weight of a carcass, meat and breast muscles as well as with the percentage content of breast muscles in the carcass. The same measurement taken after slaughter showed a high correlation with all analyzed traits except for the percentage content of fat with skin in the carcass. The coefficients of correlation between the analyzed traits, characterizing meatiness in females, were in most cases slightly higher than in males.

Keywords: broiler chickens, breast muscle thickness, fatness, meatiness, ultrasonography

\section{Zusammenfassung}

\section{Vergleich der mittels Ultraschall gemessenen Brustmuskeldicke und einzelnen Schlachtmerkmalen von Broilern}

Ziel der Untersuchung bestand im Vergleich der mit mittels Ultraschall gemessener Brustmuskeldicke und einzelnen Schlachtmerkmalen bei Broilern. Einbezogen waren 80 Ross 308 Broiler mit gleichen Geschlechteranteilen im Alter von 42 Tagen. Nach der Wägung erfolgte die Ultraschallmessung der Brustmuskeldicke (Dramiński Animal Scanner) und nach der Schlachtung eine weitere Brustmuskeldickenmessung mit Ultraschall und einer Nadelsonde sowie die Zerlegung der Schlachtkörper. Bei den männlichen Tieren ergaben sich positive, mittlere Korrelationskoeffizienten für die Lebendmessung zum Fleisch und Brustmuskelfleischgewicht sowie dem Brustmuskelanteil. Die Ultraschallmessungen an geschlachteten männlichen Tieren waren fast zu allen erfassten Merkmalen hochsignifikant. Das galt auch für die Sondenmessungen. Die Beziehungen sowohl der Lebend- als auch der Schlachtkörpermessungen mit Ultraschall oder Sonde 
bei weiblichen Tieren waren, mit Ausnahme bei Beinmuskulatur sowie Haut mit Fett, zu allen wesentlichen Schlachtmerkmalen hochsignifikant.

Schlüsselwörter: Broiler, Brustmuskeldicke, Fettanteil, Fleischanteil, Ultraschall

\section{Introduction}

Carcass meatiness is reflected primarily in the content of breast and leg muscles (BERRI et al. 2005, DUCLOS et al. 2006, STRAKOVA et al. 2006). As demonstrated in numerous studies, breast muscle thickness is a good indicator of the content of the above elements in carcasses of chickens (MICHALIK et al. 1999, RYMKIEWICZ and BOCHNO 1999).

BOCHNO (1983) analyzed research results concerning indirect methods for slaughter quality estimation in birds, and concluded that the measurement of breast muscle thickness may be a useful tool in breeding work aimed at increasing carcass meatiness in poultry. An high correlation between those traits was also observed in broiler chickens (MICHALIK et al. 1999, 2000).

Numerous studies described non-invasive methods to recording meat and fat content in poultry, for example magnetic tomography (KALLWEIT et al. 1994) or computer tomography (ANDRASSY-BAKA et al. 2003).

The ultrasonic measurement of breast muscle thickness is a quick, easy and - which is particularly important - non-invasive method, and therefore it can be successfully applied for the purpose of poultry carcass evaluation. The use of various ultrasonic devices for measuring breast muscle thickness has been described by MICHALIK et al. (1999), RÉMIGNON et al. (2000), SŁOWIŃSKI (2005). KÖNIG and GRASHORN (1997) and KÖNIG et al. $(1997,1998)$ proposed to use a 2D image obtained by ultrasound scanning to determine in vivo breast muscle yield in broiler chickens.

Since previous findings in this area were somewhat ambiguous, the objective of the present study was to determine relationships between breast muscle thickness measured using ultrasonography and meatiness and fatness traits in broiler chickens.

\section{Material and methods}

The experiment was conducted on 80 Ross 308 chickens aged 42 days (sex ratio 1:1). Breast muscle thickness was determined before and after slaughter, using an ultrasonic diagnostic apparatus (Dramiński Animal Scanner with an abdominal, sector mechanical probe, filtration of the signal $-7 \mathrm{MHz}$, penetration depth $-7 \mathrm{~cm}$ ). The measurement was performed on the right breast muscle of hanging birds, at the point situated $3 \mathrm{~cm}$ from the beginning of the breast-bone crest and $1.5 \mathrm{~cm}$ from its edge (Figure 1). Breast muscle thickness was also estimated post mortem with a needle catheter (Figure 2). This invasive method involves inserting a needle into the breast muscle, so it is not recommended for live animals.

The chickens were fasted for $12 \mathrm{~h}$, and then they were weighed and sacrificed. The carcasses (without head and feet) were chilled at $+4^{\circ} \mathrm{C}$. On the next day they were weighed and cut into pieces (neck, wings, legs, breast, back). The pieces were weighed and then they were subjected to detailed dissection into meat, bones, skin with 
subcutaneous fat, and intermuscular fat. Breast muscles (superficialis and profundus) were also dissected. The term »skin with fat" refers to both intermuscular fat and skin including a fat layer situated underneath, which are joined together and thus extremely difficult to separate.

Numerical data were processed statistically, calculating arithmetic means $(\bar{x})$, standard errors of the mean $(S E)$, standard deviations $(S D)$ as well as the coefficients of simple correlation $\left(r_{x y}\right)$ between breast muscle thickness $(x)$ and the characteristics of meatiness and fatness $\left(y_{i}\right)$ in broiler chickens (males and females was analysed separately). The significance of differences between the mean values of traits for males and females was determined by a one-factorial analysis of variance (males and females was analysed together; StatSoft 2001).

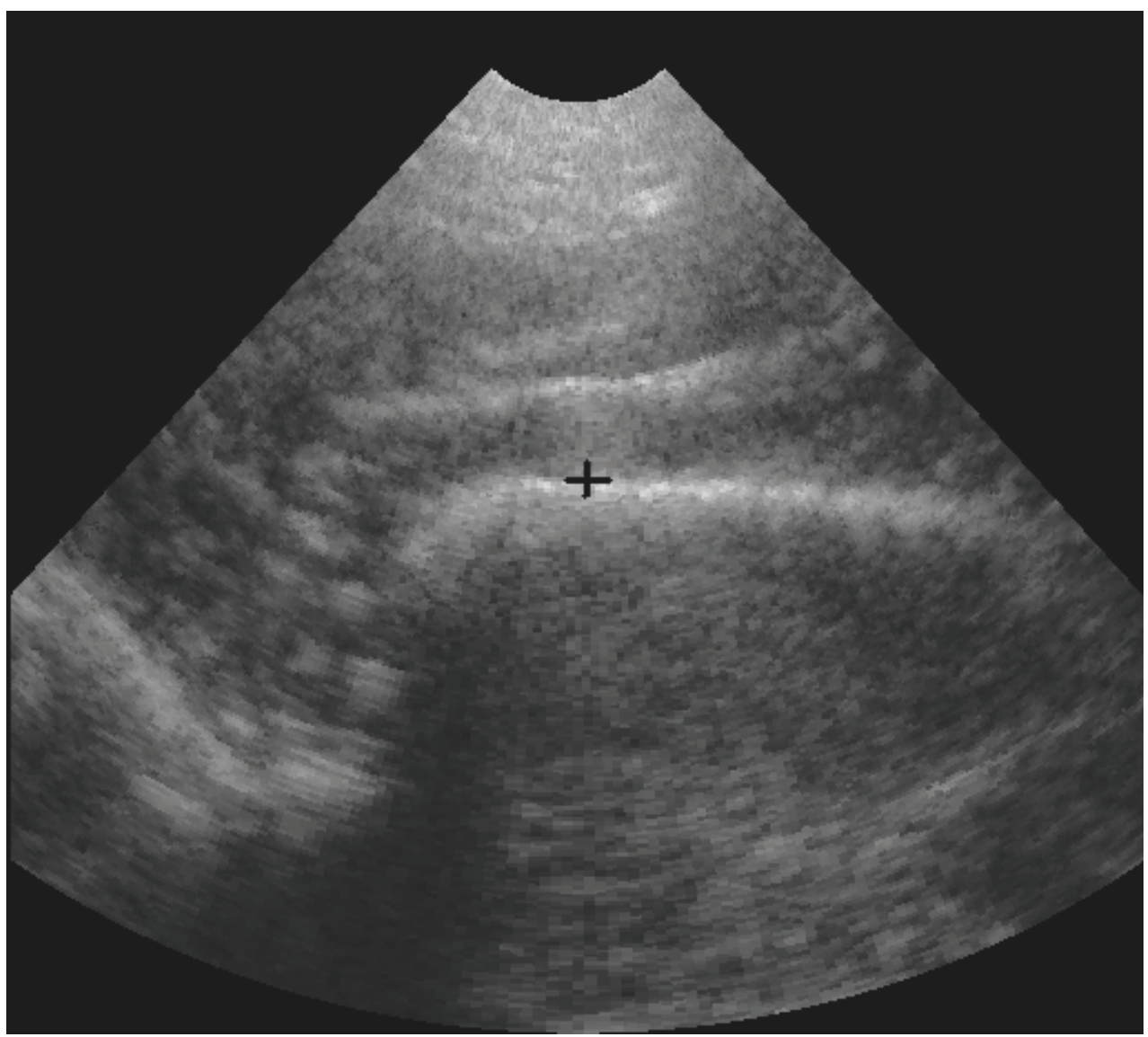

Figure 1

Image with apparatus ultrasound scan. Marked place with cross - cursor on the breast-bone crest.

Bild mittels Sonografie erhalten. Das Kreuz zeigt die Anlage des Cursors an dem Brustbein, das die Messung der Brustfleischdicke ermöglicht. 


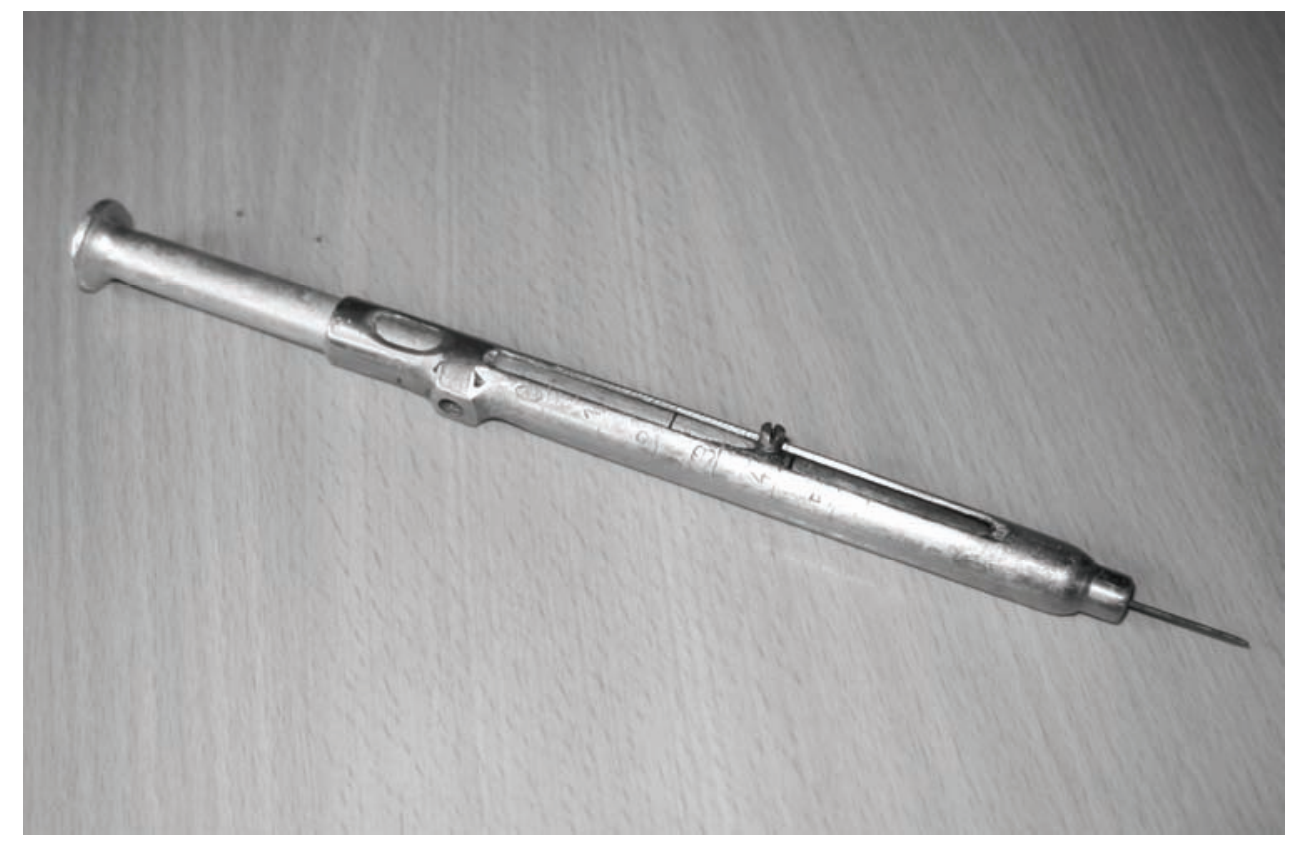

Figure 2

Needle catheter

Die Nadelsonde

\section{Results}

At the completion of the experiment the body weights of males were higher than the body weights of females (2775 g vs. $2355 \mathrm{~g}$, Table 1), which resulted in significant differences in carcass weight (1943 g and $1646 \mathrm{~g}$ respectively) as well as in the weight of the other tissue components except for skin with fat. As regards the percentage content of particular tissue components, the proportion of breast muscles and skin with fat was higher in females, while the proportion of leg muscles was higher in males (Table 1).

In males breast muscle thickness measured before slaughter was found to be significantly correlated with the weight of a carcass, meat and breast muscles as well as with the percentage content of breast muscles in the carcass ( $r_{x y}$ from 0.38 to 0.47 , Table 2$)$. The same measurement taken after slaughter showed a high correlation with all analyzed traits except for the percentage content of skin with fat in the carcass $\left(r_{x y}\right.$ from 0.33 to 0.71 , Table 2). The highest correlation was observed between this measurement and the weight and percentage content of breast muscles in the carcass $\left(r_{x y}=0.71\right.$ and 0.61 respectively), followed by total meat weight $(0.58)$, while the values recorded for leg muscles were substantially lower ( 0.35 and -0.34 respectively). Breast muscle thickness may be also a good indicator of the weight of skin with fat in carcasses of broiler chickens $\left(r_{x y}=0.49\right)$. However, it is not significantly correlated with the percentage content of skin with fat $\left(r_{x y}=0.24\right)$. 
Table 1

Arithmetic means $(\bar{x})$, standard deviations (SD) and standard errors of the mean (SE) for the investigated traits of broiler chickens

Mittelwerte, Standardabweichung und Standardfehler der erfassten Merkmale

\begin{tabular}{|c|c|c|c|c|c|c|c|c|}
\hline \multirow{2}{*}{ Specification } & \multicolumn{4}{|c|}{ Males } & \multicolumn{4}{|c|}{ Females } \\
\hline & & \multicolumn{2}{|c|}{$\bar{x} \pm S E$} & \multirow[t]{2}{*}{$S D$} & \multicolumn{3}{|c|}{$\bar{x} \pm S E$} & $S D$ \\
\hline \multicolumn{8}{|c|}{ Breast muscle thickness $(\mathrm{mm})$ measured with } & \\
\hline Ultrasound scanner before slaughter & 27.8 & \pm & 0.5 & 3.0 & 27.6 & \pm & 0.5 & 3.2 \\
\hline Ultrasound scanner after slaughter & 31.0 & \pm & 0.4 & 2.7 & 30.4 & \pm & 0.5 & 3.5 \\
\hline Needle catheter after slaughter & 30.1 & \pm & 0.4 & 2.7 & 30.1 & \pm & 0.65 & 3.3 \\
\hline \multicolumn{9}{|l|}{ Weight of, $\mathrm{g}$} \\
\hline Body & $2775.0^{* *}$ & \pm & 39.2 & 260.0 & 2355.0 & \pm & 29.4 & 193.1 \\
\hline Carcass & $1943.0^{* *}$ & \pm & 27.1 & 179.6 & 1646.0 & \pm & 24.0 & 157.1 \\
\hline Total meat & $1278.0^{* *}$ & \pm & 19.8 & 131.1 & 1073.7 & \pm & 16.8 & 110.3 \\
\hline Breast muscles & $498.0^{* *}$ & \pm & 9.6 & 63.4 & 436.2 & \pm & 8.9 & 58.6 \\
\hline Leg muscles & $452.8^{* *}$ & \pm & 7.3 & 48.4 & 361.0 & \pm & 5.3 & 34.8 \\
\hline Fat with skin & 271.7 & \pm & 5.6 & 37.0 & 258.5 & \pm & 6.2 & 40.4 \\
\hline \multicolumn{9}{|l|}{ Percentage in a carcass of } \\
\hline Breast muscles & 25.58 & \pm & 0.24 & 1.61 & $26.45^{* *}$ & \pm & 0.31 & 2.01 \\
\hline Leg muscles & $23.30^{* *}$ & ${ }^{*} \pm$ & 0.17 & 1.11 & 21.96 & \pm & 0.15 & 0.99 \\
\hline Total meat & 65.91 & \pm & 0.24 & 1.57 & 65.35 & \pm & 0.28 & 1.81 \\
\hline Fat with skin & 14.0 & \pm & 0.19 & 1.27 & $15.70^{* *}$ & \pm & 0.26 & 1.68 \\
\hline
\end{tabular}

Means followed by ** are significantly different at $\alpha=0.01$.

Table 2

Coefficients of simple correlation between breast muscle thickness $(x)$ and the investigated traits in males $\left(y_{i}\right)$ Korrelationskoeffizienten zwischen Brustmuskeldicke und Schlachtmerkmalen männlicher Tiere $\left(y_{i}\right)$

\begin{tabular}{|c|c|c|c|}
\hline \multirow{3}{*}{ Dependent variables $\left(y_{i}\right)$} & \multicolumn{3}{|c|}{ Coefficients of simple correlation $r_{x y}$} \\
\hline & \multicolumn{2}{|c|}{ Ultrasound scanner } & \multirow{2}{*}{$\begin{array}{l}\text { Needle catheter } \\
\text { after slaughter }\end{array}$} \\
\hline & before slaughter & after slaughter & \\
\hline \multicolumn{4}{|l|}{ Weight of, $\mathrm{g}$} \\
\hline Body & 0.19 & $0.47^{* *}$ & $0.38^{*}$ \\
\hline Carcass & $0.38^{*}$ & $0.56^{* *}$ & $0.52^{* *}$ \\
\hline Total meat & $0.38^{*}$ & $0.58^{* *}$ & $0.54^{* *}$ \\
\hline Breast muscles & $0.47^{* *}$ & $0.71^{* *}$ & $0.67^{* *}$ \\
\hline Leg muscles & 0.23 & $0.35^{*}$ & $0.33^{*}$ \\
\hline Skin with fat & 0.24 & $0.49^{* *}$ & $0.41^{* *}$ \\
\hline \multicolumn{4}{|l|}{ Percentage in a carcass of } \\
\hline Breast muscles & $0.40^{*}$ & $0.61^{* *}$ & $0.57^{* *}$ \\
\hline Leg muscles & -0.20 & $-0.34^{*}$ & -0.31 \\
\hline Total meat & 0.16 & $0.33^{*}$ & 0.28 \\
\hline Skin with fat & -0.01 & 0.24 & 0.14 \\
\hline
\end{tabular}

ultrasound scanner breast muscle thickness measured with ultrasound scanner, needle catheter breast muscle thickness measured with needle catheter, coefficients of correlation $\left(r_{x y}\right)$ significant at ${ }^{*} \alpha=0.05,{ }^{* *} \alpha=0.01$

The values of coefficients of simple correlation between the measurement of breast muscle thickness performed with a needle catheter and the investigated traits were at an intermediate level in relation to those obtained during ultrasonic measurements taken before and after slaughter (Table 2). The coefficients of correlation between the analyzed meatiness traits were in most cases slightly higher in females than in males (Table 3). The 
ultrasonic measurement of breast muscle thickness in live female birds was found to be considerably correlated with the weight of a carcass, meat and breast muscles $\left(r_{x y}=0.62\right.$, 0.62 and 0.67 respectively). The respective values of $r_{x y}$ obtained for the same measurement performed on carcasses were similar, although somewhat higher (Table 3). Just like in males, also in females the values of coefficients of simple correlation obtained for breast muscle thickness measured with a needle catheter post mortem were at an intermediate level, compared to the results provided by ultrasonography before and after slaughter (Table 3).

Table 3

Coefficients of simple correlation between breast muscle thickness $(x)$ and the investigated traits in females $\left(y_{i}\right)$ Korrelationskoeffizienten zwischen Brustmuskeldicke und Schlachtmerkmalen weiblicher Tiere $\left(y_{i}\right)$

\begin{tabular}{lccc}
\hline \multirow{2}{*}{ Dependent variables $\left(y_{i}\right)$} & \multicolumn{3}{c}{ Coefficients of simple correlation $r_{x y}$} \\
& Ultrasound scanner & $\begin{array}{c}\text { Needle catheter } \\
\text { after slaughter }\end{array}$ \\
\hline Weight of, g & & & \\
Body & $0.46^{* *}$ & $0.45^{* *}$ & $0.44^{*}$ \\
Carcass & $0.62^{* *}$ & $0.63^{* *}$ & $0.61^{* *}$ \\
Total meat & $0.62^{* *}$ & $0.68^{* *}$ & $0.61^{* *}$ \\
$\quad$ Breast muscles & $0.67^{* *}$ & $0.75^{* *}$ & $0.64^{* *}$ \\
$\quad$ Leg muscles & $0.44^{* *}$ & $0.44^{* *}$ & $0.45^{* *}$ \\
Skin with fat & $0.53^{* *}$ & $0.39^{*}$ & $0.44^{* *}$ \\
Percentage in a carcass of & & & \\
Breast muscles & $0.45^{* *}$ & $0.59^{* *}$ & $0.43^{* *}$ \\
Leg muscles & $-0.38^{*}$ & $-0.38^{*}$ & -0.31 \\
Total meat & 0.21 & $0.41^{*}$ & 0.26 \\
Skin with fat & 0.24 & 0.03 & 0.12 \\
\hline
\end{tabular}

ultrasound scanner breast muscle thickness measured with ultrasound scanner, needle catheter breast muscle thickness measured with needle catheter, coefficients of correlation $\left(r_{x y}\right)$ significant at ${ }^{*} \alpha=0.05,{ }^{* *} \alpha=0.01$

\section{Discussion}

The possibility to determine meat content in live birds is essential in breeding work directed towards improving carcass meatiness. Rapid estimation of both meatiness and fatness is also a key element of carcass quality evaluation, and it is best performed by non-invasive techniques.

In birds carcass meatiness is greatly dependent on breast muscle content. Thus, particular attention should be paid to the measurement of breast muscle thickness, especially that some authors (MICHALIK et al. 1999, RYMKIEWICZ and BOCHNO 1999) have stressed a significant correlation between breast muscle thickness and the content of breast muscles and meat in poultry carcasses. RYMKIEWICZ and BOCHNO (1998) postulated that breast muscle thickness in ducks may be a much better predictor of the weight of these muscles than body weight ( $r=0.905$ and 0.634 respectively).

The present study indicated that the measurement of breast muscle thickness performed on carcasses showed a slightly higher correlation with the weight of meat (including breast muscles) than the same measurement taken on live birds. The values of the coefficients of correlation between this measurement carried out on live birds and the weight of breast muscles, both in males and females, were found to be high, reaching 
0.71 and 0.75 respectively (Tables 2 and 3). The findings of OVIEDO-RONDON et al. (2007) are also interesting. These authors studied relationships between the surface area of breast muscles determined based on an ultrasonic image, and breast muscle weight and total meat weight in broiler chickens. This measurement was correlated to a higher degree with the above meatiness traits when taken on the right breast muscle, compared to the left breast muscle.

The overall quality of poultry carcasses is affected not only by meat content, but also by fat content. It should be noted here that in birds subcutaneous fat is usually dissected together with skin. The fat content of poultry carcasses is characterized by high variation, which makes it difficult to assess fatness by indirect methods (SHAHIN and ABD EL AZEEM $2005,2006)$. In the current experiment the coefficients of simple correlation between the ultrasonic measurement of breast muscle thickness performed before and after slaughter and the fat content of carcasses of both males and females were generally low and nonsignificant. In males this measurement proved to be more useful for fatness determination when taken post mortem $\left(r_{x y}=0.49\right)$, whereas in females - when performed in vivo ( $r_{x y}=0.53$, Tables 2 and 3$)$. Certain problems with an accurate indirect assessment of carcass fatness were also encountered in studies on other poultry species (BOCHNO 1983).

In conclusion in males breast muscle thickness measured before slaughter was found to be statistically significantly correlated with the weight of a carcass, meat and breast muscles as well as with the percentage content of breast muscles in the carcass. The same measurement taken after slaughter showed a high correlation with all analyzed traits except for the percentage content of skin with fat in the carcass. The coefficients of correlation between the analyzed meatiness traits were in most cases slightly higher in females than in males. The values of coefficients of simple correlation between the measurement of breast muscle thickness performed with a needle catheter and the investigated traits were at an intermediate level in relation to those obtained during ultrasonic measurements taken before and after slaughter.

An analysis of relationships between meatiness traits and breast muscle thickness measured with a needle catheter (invasive, but precise method) revealed that meatiness can be also determined in broiler chickens with an ultrasound scanner (non-invasive technique), both in vivo and post mortem.

\section{References}

Andrassy-Baka G, Romvari R, Milisits G, Sütö Z, Szabo A, Locsmandi L, Horn P (2003) Non-invasive body composition measurement of broiler chicken between 4-18 weeks of age by computer tomography. Arch Tierz 46, 585-95

Berri C, Debut M, Lebihan-Duval E, Sante-Lhoutellier V, Hattab N, Jehl N, Duclos MJ (2005) Technological quality of broiler breast meat in relation to muscle hypertrophy. Arch Tierz 48 SI, 131

Bochno R (1983) Indirect methods for slaughter quality evaluation in poultry. Prz Nauk Lit Zoot 3, 44-63 [in Polish]

Duclos MJ, Molette C, Guernec A, Remingnon H, Berri C (2006) Cellular aspects of breast muscle development in chicken with high or low growth rate. Arch Tierz 49 SI, 147-51

Kallweit E, Wesemeier HH, Smidt D, Baulain U (1994) Application of magnetic-resonance-measurements in Animal Research, Arch Tierz 31, 105-20 [in German]

König T, Grashorn MA, Bassei W (1997) Estimation of breast meat yield in living broilers using B-scan sonography. I. Defining sites of measurement. Arch Geflügelk 61, 227-31 
König T, Grashorn MA, Bassei W (1998) Estimation of breast meat yield in living broilers using B-scan sonography. II. Accuracy measurement of breast meat. Arch Geflügelk 62, 121-5

König T, Grashorn MA (1997) Real-time sonography for selection on meat yield in broilers. In 13th European Conf On the Quality of Poultry Meat, Poznan, Poland, 601-6

Michalik D, Bochno R, Janiszewska M, Brzozowski W (1999) In vivo assessment of meatiness and fatness in broiler chickens using ultrasonography. Pr Mater Zoot 54, 77-83 [in Polish]

Michalik D, Bochno R, Wilkiewicz-Wawro E, Lewczuk A (2000) The regression equations for in vivo estimation of breast muscles content in chickens. Zesz Nauk PTZ Prz Hod 49, 224 [in Polish]

Oviedo-Rondón EO, Parker J, Clemente-Hernández S (2007) Application of real-time ultrasound technology to estimate in vivo breast muscle weight of broiler chickens. Brit Poultry Sci 48, 154-61

Rémignon $\mathrm{H}$, Seigneurin $\mathrm{F}$, Moati $\mathrm{F}(2000)$ In vivo assessment of the quality of breast muscle by sonography in broilers. Meat Sci 56, 133-8

Rymkiewicz J, Bochno R (1998) Regression equations for in vivo estimation of the breast muscle content in ducks. Zesz Nauk PTZ Prz Hod 36, 101-7 [in Polish]

Rymkiewicz J, Bochno R (1999) Estimation of breast muscle weight in chickens on the basis of live measurements. Arch Geflügelk 63, 229-33

Shahin KA, Abd El Azeem F (2005) Effects of breed sex and diet and their interactions on carcass composition and tissue weight distribution of broiler chickens. Arch Tierz 48, 612-26

Shahin KA, Abd El Azeem F (2006) Effects of breed sex and diet and their interactions on fat deposition and partitioning among depots of broiler chickens. Arch Tierz 49, 181-93

Słowiński M (2005) Studies into the application of rapid indirect methods to evaluate the quality of poultry carcasses and meat. Rozpr Nauk Monogr Wyd SGGW Warszawa, 3-130

StatSoft (2001) Statistica version 6

Strakova E, Suchy P, Vitula F, Vecerek V (2006) Differences in the amino acid composition of muscles from pheasant and broiler chickens. Arch Tierz 49, 508-14

Received 17 January 2008, accepted 22 July 2009.

Corresponding author:

KATARZYNA KLECZEK

email: katarzyna.kleczek@uwm.edu.pl

Department of Commodity Science and Animal Improvement, University of Warmia and Mazury,

Oczapowskiego 5, Olsztyn, Poland 